abolition of any legislative authorization of permissible investments for corporate trustees may be desirable. ${ }^{115}$ Asserted competence and problems peculiar to the corporate fiduciary have long justified separate and distinctive treatment from that pertaining to the individual trustee. ${ }^{110}$ Retention of the restrictive legal lists for individuals, and reversion to the unrestrained discretion of the Massachusetts rule for corporate trustees would seem to offer the best solution of the problem presented. With the removal of all stigma of unconformity to statutory prescription, discretion would be complete, and such excuses for faulty investment policies nullified. ${ }^{117}$ To compensate for thus extending the powers of the corporate fiduciary and insure proper protection for the beneficiaries, adequate authority already exists for imposing upon such trustees standards of care more exacting than those required of the individual. ${ }^{118}$ Further, examination of trust portfolios by trained bank and trust company examiners, analogous to that now imposed upon banking departments, would be warranted. ${ }^{110}$ "Prudence," although still undefinable, may then assume new meanings for the professional antagonist of legislative restraints.

\title{
UNACCOMPLISHED REFORMS IN PARTNERSHIP BANKRUPTCY UNDER THE CHANDLER ACT
}

THE peculiar features of the tenancy in partnership have never been satisfactorily fitted to the pattern of bankruptcy procedure in the United States. Prodigious efforts have been devoted to modernizing the remedies for corporations, ${ }^{1}$ but partnerships have been clumsily adjusted to the bankruptcy rules applicable to individuals. ${ }^{2}$ The adjustment was not so difficult under the Bankruptcy Act of 1867 , for it provided that partnership assets could

115. Trust companies are thus uninhibited in Massachusetts and states relying solely upon the prudence rule for beneficiary protection. See note 12 supra.

116. But sce Indiana Trust Co. v. Griffith, 176 Ind. 643, 95 N. E. 573 (1911) raising constitutional issues of unlawful discrimination.

117. See note 113 sipra.

118. See In re Allis' Est., 191 Wis. 23, 209 N. W. 943 (1926); In re Clark's Est., 136 Misc. 881, 242 N. Y. Supp. 210 (Surr. Ct. 1930), Stephenson, Accepting The Challcngc For Highest Standards In Trust Administration (1931) 53 Trust Co. 491; (1930) 29 MICH. L. REv. 125.

119. Following unfavorable publicity of lax standards disclosed in depression cases, bank examiners extended their supervision into the hitherto largely unsupervised trust departments. Neilan, Activities of Bank Examiners With Respect To Trust Funds (1938) 5 Law \& Contemr. Prob. 462.

1. Notably $\S 77 B, 48$ Stat. 912,11 U. S. C. $\$ 207$ (1934), and its successor, Chapter X, 52 STaT. 883 et seq., 11 U. S. C. $\$ \$ 501-676$ (Supp. 1938).

2. The approach taken by the drafters of the Act is indicated by the words of $\S 5 \mathrm{c}$, 52 Stat. 845, 11 U. S. C. § 23c (Supp. 1938) : "In other respects, so far as possible, the partnership estate shall be administered as herein provided for other estates." 
not be administered in bankruptcy without adjudication of all the partners. ${ }^{3}$ Thus, the Act provided a satisfactory basis for the administration of firm and individual property in one proceeding and for the subsequent discharge of the adjudicated partners. 4 But this solution of the partnership bankruptcy problem made it unduly difficult for the court to obtain jurisdiction of an insolvent firm. The 1898 Act removed the jurisdictional difficulty by defining a partnership as a "person"s and allowing its adjudication in bankruptcy as a unit separate from the partners composing it, ${ }^{\circ}$ so that a firm could be adjudicated and its assets administered in bankruptcy without regard to partners who could not be adjudicated because of infancy, insanity, ${ }^{8}$ exemptions $^{9}$ or death. ${ }^{10}$

In allowing the separate adjudication of the firm, however, the 1898 Act raised problems not present under the older Act, as to the separateness of treatment of firm and partners for other purposes. Many of these problems were not provided for in the Act, and unfortunately the courts approached them unrealistically in terms of competing "theories" of the nature of a part-

3. Rev. Stat. \$5121 (1875); see In re J. M. Ceballos \& Co., 101 Fed. 451, 452 (D. N. J. 1908); Comment (1929) 29 COL. L. REv. 1134.

4. 1 Collies ox BaxkRiptcy (14th ed. 1940) $\$ 5.01$.

5. 35 Star. 838 (1909), 11 U. S. C. \$1(19) (1934). Under $\$$ to any "person" (with certain exceptions not relevant) may be a voluntary bankrupt. Under $\$ 4 \mathrm{~b}$ any "natural person except a wage earner or farmer . . . may be adjudged an involuntary bankrugt." An interesting problem has arisen under these sections as to how literally the definition of a partnership as a "person" under $\$ 1(19)$ is to be taken. Is a partnership which derives the principal part of its incone from farming tu be regarded as "personally engaged in farming" within $\$ 1(17)$ so as to be exemrt from involuntary adjudication under $\$$ th? Despite logical difficulties, such exemption has been granted by the courts. H. D. Still's Sons v. American Nat. Bank, 209 Fed. 749 (C. C. A. fth, 1913); 1 CoLluer 0: BanssBUPTCY (14th ed. 1940) 614-615, 702.

6. Section 5a, 30 Stat. 547 (1898), 11 U. S. C. $\$ 23 a$ (1934). Under the 1867 Act, partnerships were not adjudicated bankrupt; the trustee of the adjudicated partners drew to himself the administration of the firm and separate estates. See In re Mleyer, 98 Fed. 976, 979 (C. C. A. 2d, 1899); 1 CoLLIER ox B.ANkRtrter (14th. ed. 1940) \$ 5.01.

7. In re Dumigan, 95 Fed. 428 (D. Afass. 1899); In re Duguid, 100 Fed. 274 (E. D. N. C. 1900).

S. In re L. Stein \& Co., 127 Fed. 547 (C. C. A. 7th, 1904).

9. Dickas v. Barnes, 140 Fed. S49 (C. C. A. 6th, 1905) (a partnership, some of whose members are farmers and wage-earners exempt from adjudication as involuntary bankrupts, may nonetheless be adjudicated an involuntary hankrupt); In re Dixon, $18 \mathrm{~F}$. (2d) 961 (W. D. Mich. 1926) (Though a wife is exempt from adjudication in banl:ruptcy under Michigan statutes, a partnership of which she vas a member may ba declared bankrupt). See 1 Coliner on BaNerupteY (14th ed. 1940) $\$ 5.10$.

10. Meek v. Beezer, 28 F. (2d) 343 (C. C. A. 3d, 1928), cert. derricd, 278 U. S. 651 (1929) ; In re Coe, 157 Fed. 308 (S. D. N. Y. 1907); Ins re Wells, 298 Fed. 109 (S. D. Ohio 1924). There is a conflict as to whether the estate of a deceased partner ean ba held liable for partnership debts incurred after his death. Compare In re Evans, 161 Fed. 590 (N. D. Ga. 1908), with Blumer Brewing Corp. v. MYayer, 223 Wis. 540,269 N. W. 693 (1936). See Note (1936) 25 Gro. L. J. 1048; Comment (1903) S CoL. L. Rev. 391. 
nership - some affirming and some denying that a firm is for bankruptcy purposes a self-sufficient "entity." 11 Some of the resulting conflicts of decision as to the procedural treatment of firm and partners, where both are before the court, have been removed by the Chandler Act. ${ }^{12}$ But the seeds of the controversy which has wasted and misdirected the energy of the courts for * decades remain. ${ }^{13}$

Neither of the competing theologies of partnership law is adequate in itself to account for the actual system of administration in partnership bankruptcy. For some purposes the firm and partners may be said to be separate. Both have separate assets, and separate creditors; in recognition of this the Act requires separate accounts for the two estates in a joint proceeding in bankruptcy, ${ }^{14}$ and provides that firm creditors shall have first claim on firm, individual creditors first claim on individual, assets. ${ }^{15}$ For other purposes, the individual and firm estates bear a very close relation to each other. The partners, and hence their creditors, have no direct claim on firm assets, but have a right on dissolution to their share in the surplus of firm assets after payment of firm debts; this interest may be available without direct interference of the court with the assets of the firm. ${ }^{10}$ The partners, on the other hand, are directly liable for the firm debts - none the less because payment from their estates is made first to their private creditors. ${ }^{17}$ This means that the surplus of the individual estates over individual debts is a firm asset, within the direct power of the firm trustee $;^{18}$ it means that the assets of

11. Warren, Corporate Advantages Without Incorporation (1929) 29-140; Hough, Some New Aspects of Partnership Bankruptcy Under the Act of ISgS (1908) 8 Col. L. Rev. 599; Comments (1929) 29 Col. L. Rev. 1134, (1928) 41 Hakv. L. Rev. 1044, (1911) 10 Mich. L. Rev. 215, (1908) 8 CoL. L. Rev. 391.

12. The professed aim of the Chandler Act was to provide a more workable system of partnership bankruptcy. H. R. REP. No. 1409, 75th Cong., 1st Sess. (1937) 3; SEN. REP. No. 1916, 75th Cong., 3d Sess. (1938) 3. The drafters of the Act apparently thought this end could be attained without fundamental revision. See the list of proposed reforms in Analysis of H. R. 12889, 74th Cong., 2d Sess. (1936) 21 (hereinafter referred to as Analysis) ; 1 Collier on BANkruptcy (14th ed. 1940) 686-687.

13. Commentators discussing the Chandler Act have already differed over the theory on which it is principally based. McLaughlin, Aspects of the Chandler Bill to Amend the Bankrtptcy Act (1937) 4 U. of CHI. L. Rev. 369, 378, n. 42 (entity theory); Comment (1938) 87 U. of PA. L. REv. 105 (aggregate theory).

14. Section 5e, 52 Stat. 845,11 U. S. C. \$23e (Supp. 1938).

15. Section 5g, 52 Stat. 845, 11 U. S. C. $\$ 23 g$ (Supp. 1938). See Uniform PaltNERSHIP ACT $\S 40$.

16. Uniform Partnership Act $\$ \$ 25-28,40$; Crane, Partnership (1938) 150-168, 404. See Comment (1925) 39 Harv. L. Rev. 247.

17. Gordon v. Texas Co., 119 Me. 49, 109 Atl. 368 (1920), In re Latghlin, 96 Fed. 589 (N. D. Iowa 1899). See Francis v. McNeal, 228 U. S. 695, 699 (1913); UntFous ParTnership ACT $\$ 15$.

18. Dickas v. Barnes, 140 Fed. 849 (C. C. A. 6th, 1905); In re Sugar Valley Gin Co., 292 Fed. 508 (N. D. Ga. 1923) ; Comment (1928) 41 HArv. L. Rev. 1044, 1046-1047. See In re Samuels \& Lesser, 207 Fed. 195, 196-197 (S. D. N. Y. 1913), rev'd on othcr 
the partners must be considered in measuring firm solvency, ${ }^{19}$ and administered or accounted for in the firm proceeding. ${ }^{-0}$

These basic rules of joint liability and priority on distribution, talien from the Uniform Partnership Act and the non-statutory law of partnership, form the foundation of the partnership system of the Bankruptey Act. That this involves the adoption, for different purposes and in different contexts, of hoth the "entity" and the "aggregate" theories of partnerships, is not a repruach to the drafters of the Act; no other course could have been taken without revolutionizing the rules and risks long accepted as incident to the partnership business unit. But the Act is not always skillful in providing machinery adequate to enforce those rules in such a way as to achieve the efficient administration of assets in the interests of creditors, and the new start for debtors, which constitute the accepted aims of bankruptcy proccedings.

The question of what is a partnership for bankruptey purposes is not settled by Section 5.21 To come within the section, an individual must lie sluwn to be an actual partner, an organization to be an actual partnership, under the applicable provisions of state law. 2 These provisions in general supply a sufficiently workable test, though there may be difficulty in applying them to certain organizations, like unincorporated companies, which combine features of partnerships and corporations. ${ }^{23}$ On the subject of one such type of

grotnds sab nom. In re Samuels, 215 Fed. S45 (C. C. A. 2d, 1914); Usifors P.tmaterSHIP ACT $\$ 40$ (a) (II) (by implication).

19. Vaccaro v. Security Bank, 103 Fed. 436 (C. C. A. 6th, 1900); Fort Pitt Coal and Coke Co. v. Diser, 239 Fed. 443 (C. C. A. 6th, 1917); In re Perlheiter, 177 Fed. 299 (S. D. N. Y. 1910) ; In re Blair, 99 Fed. 76 (S. D. X. Y. 1900); Comments (1930) 15 St. Louis L. Rev. 209; (1908) 8 Col. L. Rev. 391, 598; Crase, Part:iersnip (1933) 399. Contra: In re Everybody's Grocery \& Meat Mrarket, 173 Fed. 492 (D. Okla. 1968); In re McMurtrey \& Smith, 142 Fed. 853 (IV. D. Tex. 1905). These cases are bassd on strict application of the entity theory and may be considered virtually overruled by Francis v. McNeal, 228 U. S. 695 (1913).

20. Francis v. MIcNeal, 228 U. S. 695 (1913); Armstrong v. Fisher, 224 Fed. 97 (C. C. A. 8th, 1915) ; Comment (1930) 15 ST. Lours L. Rev. 209.

21. 52 StAт. 845,11 U. S. C. $\$ 23 a-k$ (Supp. 1938) (the partnership section).

22. The cases hold that there can be no partnership by estoppel for bankruptey jurposes. In re Kaplan, 234 Fed. 866 (C. C. A. 7th, 1916); In re Fahey, 26 F. (2d) 382 (S. D. Tex. 1928), aff'd sub nom. Fahey v. Sapio, 30 F. (2d) 330 (C. C. A. 5th, 1929). See 1 Collier on Banknuptcr (1th ed. 1940) 6S9-691; Uniform Pant:iersmip Aet $\$ \$ 16,35$.

23. Banking organizations with some of the attributes of a corporation have bsen adjudicated as partnerships. Burkhart v. German-American Bank, 137 Fed. 958 (S. D. Ohio 1904); In re Bank of Crowell, 53 F. (2d) 6\$2 (X. D. Tex. 1931). But unincorporated insurance associations have been adjudicated as unincorporated companies under \$4b. 36 Stat. $\$ 39$ (1910), 11 U. S. C. \$22b (1934); In re Seaboard Fire Underwriters, 137 Fed. 987 (S. D. N. Y. 1905); In rc Minnesota Ins. Underwriters, 36 F. (2d) 371 (D. Minn. 1929). Under the Chandler Act, any organization which the court determines to be an unincorporated company may be adjudicated only as a cornoration. \$1(8), 52 STst. 810, 11 U. S. C. $\$ 1(\$)$ (Supp. 1938). The difficulty arises in this initial determination. No apparent distinction appears between the banking organizations which courts 
organization, however, the limited partnership, the Bankruptcy Act itself gives specific directions. Both the powers and the liabilities of a limited partner differ materially from those of a general partner, ${ }^{24}$ and the 1898 Act dealt with limited partnerships as corporations. ${ }^{25}$ This was not very logical. Since the firm and partners can be separately adjudicated, the fact that under the tests of state law the limited partners cannot be adjudicated as partners should not prevent the adjudication of the firm. Limited partnerships are essentially just general partnerships with added capital backing; they have no distinguishing features important enough to justify different treatment. In recognition of this fact, the Chandler Act has made limited partnerships and their general partners subject to Section $5,{ }^{26}$ and has provided that whenever the limited partners become subject, under state law, to the liability of general partners, they also shall come within the provisions of the section. ${ }^{27}$ The change is rounded out by a provision that distribution of the surplus of firm property after payment of firm debts shall be made to the partners, limited or general, or their estates, in the order directed by state law..$^{28}$

The judicial controversy as to the degree of separate treatment necessary for firm and partners because of the provision in the 1898 Act that the firm might be separately adjudicated, raised a number of procedural problems in the situation when the firm and some of the partners were concurrently adjudicated. One of these was settled when the Chandler Act specifically provided for filing a joint petition, in either voluntary or involuntary proceedings. ${ }^{20} \mathrm{~A}$ related problem arose as to the number of fees to which the

have treated as partnerships and the insurance associations treated as unincorporated companies. Republic Underwriters v. Ford, 100 F. (2d) 511 (C. C. A. 5th, 1938). The court's determination of the issue is important since an insurance or banking corporation is exempt from involuntary adjudication, while a banking or insurance partnership is not.

24. A limited partner is not individually liable for firm debts; he is not the agent of the firm; and his death does not work a dissolution of the firm. Analysis, 22.

25. 30 STAT. 544 (1898), 11 U. S. C. \$1(6) (1934).

26. Section 5a, 52 Stat. 845,11 U. S. C. $\$ 23 a$ (Supp. 1938).

27. Section 5k, 52 Stat. 845, 11 U. S. C. $\$ 23 k$ (Supp. 1938). Due to the fact that a limited or special partner may be held liable as a general partner, he is said to be under a "contingent unlimited liability." Warren, Corporate Advantages Without IncorporATION (1929) 306. The stringency of the rules which call this liability into effect has, however, been greatly lessened of recent years. Compare Petition of Williams, 297 Fed. 696 (C. C. A. 1st, 1924), with Giles v. Vette, 263 U. S. 553 (1924). See generally, Crane, Partnership (1938) 79-85; Comment (1935) 45 Yale L. J. 895.

28. 52 Stat. 845,11 U. S. C. $\$ 23 g$ (Supp. 1938). See Untrorn Partnersump Act $\S 40$.

29. Section 5b, 52 Stat. 845, 11 U. S. C. §23b (Supp. 1938). Under the 1898 Act some courts had refused to adjudicate partners and partnerships on a joint petition. In rc Farley, 115 Fed. 359 (W. D. Va. 1902); In re Barden, 101 Fed. 553 (E. D. N. C. 1900). Other courts had discharged partners on the basis of a partnership petition. In $r e$ Langslow et al., 98 Fed. 869 (N. D. N. Y. 1899); In re Gay, 98 Fed. 870 (D. N. H. 1899). Prior to the Chandler Act separate petitions against a partnership and its individual members were required in Virginia, North Carolina and California; while in New Hamp- 
bankruptcy officials were entitled. Clerks received a separate fee for each "estate" handled; $;^{30}$ but the trustee and referee were allotted a fee for each "case." 31 In courts which held that petitions of concurrently adjudicated firm and partners should be filed jointly, the referee and trustee were therefore sometimes confined to a single fee. 32 The Chandler Act now provides that a trustee shall receive a fee for each "estate;" 33 but referees, who still receive compensation by the "case," may find themselves limited on a joint petition to a single fee. ${ }^{34}$

In the light of the judicial controversy over the separateness of firm and partners, the filing of a joint petition raises further problems with regard to the necessary allegations. Must the requirements of the Act as to the amount of $\mathrm{debt}^{35}$ and the number of creditors ${ }^{36}$ required for the filing of an involuntary petition be separately satisfied as to each of the partners joined with the firm? If the "entity" theory is taken seriously, it would seem that they must. But the liability of each of the partners for the firm debts seems, realistically, to provide a sufficient basis for considering firm creditors as individual creditors for this purpose, and firm debts as individual debts. The case authority seems to indicate that the more practical standard will be followed, and allegations that the firm has satisfied the requirements will be deemed to confer jurisdiction of the joined partners as well. ${ }^{37}$ With regard to venue also, separate allegations seem to be unnecessary, under the provisions of subsection $5 \mathrm{~d} ;^{38}$ though careful practice requires that where a partner resides in a different district, the fact should be noted, as it may be necessary to invoke the provisions of the Act on ancillary jurisdiction. ${ }^{39}$

shire, New York, Pennsylvania and other eastern states, a joint petition was permitted. Analysis, 23.

30. 30 STAT. 559 (1898), 11 U. S. C. $\$ 80$ a (1934).

31. 30 Stat. 556 (1898), 11 U. S. C. $\$ 6 \$ a$ (1934) (referce); 36 St.4. $\$ 40$ (1910), 11 U. S. C. $\$ 76 a$ (1934) (trustee).

32. On the theory that a joint proceeding was only one case, regardless of how many estates were involved. Willis v. Hart, 11 F. (2d) 530 (C. C. A. 5 th, 1926); In re Langslow, 98 Fed. 869 (N. D. N. Y. 1899); In re City Contracting and Building Co., 30 Am. B. R. 133 (D. Hawaii 1913). Other courts, hovever, had awarded fees for each estate to referee and trustee. In re Wenz, $30 \mathrm{~F}$. (2d) 705 (M. D. Penn. 1929); In rc Thompson, 17 F. (2d) 601 (D. N. H. 1927) ; Is re Barden, 101 Fed. 553 (E. D. N. C. 1909) (each "case" means each "estate").

33. 52 StAT. 861, 11 U. S. C. \$76c (Supp. 1938).

34. See Comment (1938) 87 U. of PA. L. Rev. 105, 107.

35. Section 4 b, 52 STAT. $\$ 45$ (1938), 11 U. S. C. $\$ 22 b$ (Supp. 1938) (debts must equal or exceed $\$ 1,000)$.

36. Section 59b, 52 Stat. $\$ 68$ (1938), 11 U. S. C. $\$ 95 b$ (Supp. 1938) (three or more creditors with provable claims equal to or in excess of $\$ 500$; if all creditors are less than twelve, then one creditor with provable claims equal to $\$ 500)$.

37. See Mills v. J. H. Fisher \& Co., 159 Fed. $897,898,900$ (C. C. A. 6th, 1903).

38. 52 Stat. 845,11 U. S. C. $\$ 23 d$ (Supp. 1938); 1 Coluter or Banisturcr (14th ed. 1940$) \$ \$ 2.17,5.16$.

39. See Moore's Bankruptcy Mlanual (1939) $\$ 2.10$, p. 21 ; $\$ 2(20), 52$ St八t. 842, 11 U. S. C. \$11(20) (Supp. 1938). 
And separate prayers for relief should be included to insure the discharge of each of the partners. ${ }^{40}$

For purposes of an act of bankruptcy on an involuntary petition, the firm and partners are generally treated as separate. The underlying philosophy of acts of bankruptcy is still that of fault. ${ }^{41}$ Therefore, though a partner may provide the basis for his own adjudication and that of the firm by an act of bankruptcy which affects the firm business or disposes of the firm assets, ${ }^{42}$ the other partners cannot be adjudicated on the basis of the same act unless they to some degree participated in or ratified it. ${ }^{43}$ The evidence required for a finding of participation, however, is often slight. ${ }^{44}$ And some cases have gone to the extreme of holding that an act which justifies the firm adjudication is a basis for the concurrent adjudication of all the partners.45 Even, however, where the general rule of separate allegations with regard to acts of bankruptcy is followed, a separate allegation of the insolvency of each partner, in cases where insolvency is an issue of the alleged act of

40. The relief granted will follow the form of the prayer. In re Anderson Motor Co., 18 F. (2d) 1001 (N. D. Tex. 1927). In re John L. Russell, 97 Fed. 32 (N. D. Iowa 1899),

41. See Treiman, Acts of Bankruptcy: A Mediezal Concept in Madern Bankruptcy Law (1938) 52 Harv. L. Rev. 189.

42. A partner committing a firm act of bankruptcy with partnership assets has been held to commit simultaneously an individual act of bankruptcy. In re Meyer, 98 Fed. 976 (C. C. A. 2d, 1899); In re Perlhefter \& Shatz, 177 Fed. 299, 305 (S. D. N. Y. 1910). Contra: In re Hale, 107 Fed. 432 (E. D. N. C. 1901). Generally, the commission of an act of bankruptcy as to partnership property by one partner within the scope of his allthority amounts to an act of bankruptcy by the firm. 1 Colluer on BANRruptcr (1th ed. 1940) 696; see CRANE, PARTNership (1938) 400. However, in case the act of bankruptcy relied on is a general assignment for the benefit of creditors, an admission of inability to pay debts and a willingness to be adjudicated bankrupt, or concealment of assets with intent to defraud creditors, it is not a firm act unless the other partners have given express authority to the acting partner or can be said to have ratified or assented to his act. In re Meyer, 98 Fed. 976 (C. C. A. 2d, 1899) (general assignment ratified by inaction of the non-acting partner); In re Kersten, 110 Fed. 929 (E. D. Wis. 1901) (admission of inability to pay debts and willingness to be adjudicated bankrupt ratified by other partner's failure to object). Ini re Wellesley, 252 Fed. 854 (N. D. Cal. 1917) (concealment of assets with intent to defraud creditors ratified because the non-acting partners did not prevent or rectify the act).

An act of bankruptcy committed by an individual partner with the assets of his separate estate, even when made with intent to prefer some firm creditors over others, is not a firm act of bankruptcy. Hartman v. John Peters \& Co., 146 Fed. 82 (M. D. Pa. 1906); In re Stovall Grocery Co., 161 Fed. 882 (N. D. Ga. 1908). But it is an individual act of bankruptcy by the partner for which he may be adjudicated an involuntary bankrupt. Mills v. J. H. Fisher and Co., 159 Fed. 897 (C. C. A. 6th, 1908); Hartman v. John Peters \& Co., supra.

43. In re Meyer, 98 Fed. 976,979 (C. C. A. 2d, 1899); In $r \varepsilon$ Kersten, 110 Fed. 929 (E. D. Wis. 1901); 1 Collier on Bankruptcy (14th ed. 1940) $\$ 5.05$.

44. See note 42 supra.

45. Yungbluth v. Slipper, 185 Fed. 773 (C. C. A. 9th, 1911), cert. denied, 223 U. S. 722 (1911) ; Holmes v. Baker \& Hamilton, 160 Fed. 922 (C. C. A. 9th, 1908); 1 Coltier on BANKRUPTCY (14th ed. 1940) 697, n. 9. 
bankruptcy, ${ }^{46}$ is unnecessary, ${ }^{47}$ provided the same act is used for firm and partners. For under the prevailing rule of firm solvency, based on the liability of each of the partners for all the firm debts, a firm is insolvent only when none of the partners is solvent in the sense of being able to pay both his own and the firm debts. ${ }^{48}$

A voluntary petition is not in pursuance of, but is aimed at ending, the firm business, so that the usual mutual agency relationship of the partners is absent. ${ }^{49}$ Hence a voluntary petition in behalf of the firm must lie authorized, or at least ratified, by all the partners. ${ }^{30}$ To make a firm adjudication possible when some but not all the partners felt that the economic situation of the firm made it desirable, General Order VIII ${ }^{51}$ was promulgated under the

46. An allegation of insolvency at the time of the commission of the act of bankruptcy is necessary under the second, third and fifth acts, $\$ 3$, 52 STur. \$44, 11 U. S. C. $\$ 21$ (Supp. 1938). Solvency is also relevant as matter of defense under \$3d. Solvency at the time of the petition is a complete defense to the first act, under $\$ 3 \mathrm{c}$. See West Co. v. Lea, 174 U. S. 590 (1899); 1 Collier on BANRruptcy (14th ed. 1940) $\$ 3$. The fifth Act allows, as an alternative to the usual solvency test in bankruptey, an allegation of inability to meet debts as they mature. See Chandler stet Commenlary, 11 U. S. C. A., p. 7 (Supp. 1939).

47. See Mieek v. Beezer, 28 F. (2d) 343 (C. C. A. 3d, 1928) ; 1 COLuER 0: B.s:KRUPTCY (14th ed. 1940) 705 .

48. In re Blair, 99 Fed. 76 (S. D. N. Y. 1900); In re Griffith, 280 Fed. 878 (D. Del. 1922); In re Perley \& Hays, $13 S$ Fed. 927 (E. D. J5o. 1905); Comment (1929) 14 St. Louts L. Rev. 179; 1 Reningtox, B.ankrtptar (t th ed. 1934) \& 68; Crane, P.ritNERShip (1938) 399; 1 Collier ox Bankruptcy (1tth ed. 1930) 698; see note 19 suspra. The rule actually appears in the Chandler Act, though its application is there limited solely to determining partnership insolvency in connection with liens and fraululent transfers. $\$ 67 d(1)$ (d), 52 Star. $\$ 75$ (1938); 11 U. S. C. $\$ 107 d$ (1) (d) (Supp. 193\$). The general bankruptcy rule is that a person is insolvent when the aggregate of his assets at a fair valuation are insufficient to pay his debts. 52 ST..T. $\$ 40,11$ 乙. S. C. \$1(19) (Supp 1938). Cases adopting the entity theory in all its implications, therefore, determined partnership insolvency without reference to the assets of the individual partners. In $r c$ Bertenshaw, 157 Fed. 363 (C. C. A. \&th, 1907); In re Solomon \& Carvel, 163 Fed. $4 \% 2$ (E. D. N. Y. 1908). The reasoning of these cases, however, shared the fate of the dodo after Francis v. MrNeal, 228 U. S. 695 (1913).

On the illogical inclusion of exempt assets in determination of partnership insolvency, see McLaughlin, Aspects of the Chandler Bill to Amend the Rantruftey Aet (1937) 4 U. of CHI. L. Rev. 369, 373.

49. In re Julian, 22 F. Supp. 97 (M. D. Pa. 1938); Uniforar Pamtsensint Act $\$ 9(3)$ (c) ; Crane, Partakership (1938) 398. But the filing of a "voluntary" petition without consent of all partners may be considered an act of bankruptcy. In re Junds \& Balthazard, 169 Fed. $4 \$ 1$ (E. D. Wis. 1909); In re Forbes, 128 Fed. 137 (D. Mass. 1904).

50. ATeek v. Centre County Banking Co., 2 is U. S. 426 (1925); In rc York, is F. (2d) 428 (N. D. Tex. 1926); In re MeCloskey, 18 F. (2d) 311 (E. L. Pa. 1926); sse Comments (1927) 76 U. of P.. L. Rer. 85, (1925) 4 TEx. L. Rex. 102. Ratification by a nonjoining partner may be found from his failure to object. In re Sitnels, 52 F. (2d) 861 (W. D. Pa. 1931).

51. 1 Collmer on Baxkreptcy (1tth ed. 1940) 703. General Order VIII was sugplemented by Official Form No. 2. 
1898 Act. The order provided for a quasi-voluntary petition by less than all the partners. Creditors could not intervene, but due notice had to be given to the non-joined partners. ${ }^{52}$ If they objected, the petition was deemed involuntary as to them, and they had the right to make, under some cases, any defense open on an ordinary involuntary petition; ;3 under others, a defense only on the issue of solvency. ${ }^{54}$ On failure of the defense, the objecting partners could not themselves be adjudicated, but they could not stand in the way of the court's taking jurisdiction of the firm and the petitioning partners. ${ }^{55}$ This curious combination of a voluntary and involuntary petition was ruled invalid when the Supreme Court in 1925 abrogated General Order VIII.56 The Court held that the procedure had no basis in the 1898 Act, which provided for only two methods of adjudication - voluntary and involuntary. This method could not be termed voluntary, since some of the partners objected; nor involuntary, since the petition was not brought by creditors and did not allege an act of bankruptcy. The order was therefore held an improper legislative use of the rule-making power. ${ }^{57}$

The Chandler Act filled the procedural gap left by this case. It provided for a petition by less than all the partners, alleging firm insolvency, notice to non-assenting partners to allow them to file an answer on this isste..$^{60}$ The reform has been minimized on the ground that individual partners coutd get relief from firm debts by filing an individual voluntary petition in bankruptcy. ${ }^{60}$ This view seems unduly harsh. The change represents a significant departure from the philosophy underlying the requirement of an act of bankruptcy, ${ }^{61}$ and it provides a convenient procedure whereby full and immediate administration of the firm property may be achieved when some of the partners feel that the economic situation of the firm and its partners requires such a course. The procedure removes, for purposes of a petition by the partners, the difficulty in getting before the court which faced creditors

52. In re John L. Russell, 97 Fed. 32 (N. D. Iowa 1889); 1 Collier on BANkRUPTCY (14th ed. 1940) $§ 5.11$.

53. 1 Collier on Bankruptcy (14th ed. 1940) $\$ 5.11$.

54. Some cases rationalized the limitation of the contested issues to solvency by declaring that the filing of a partnership petition amounts to a firm act of bankruptcy. In re Forbes, 128 Fed. 137 (D. Mass. 1904); In re Junck \& Balthazard, 169 Fed. 481 (E. D. Wis. 1909). Another case stated that an act of bankruptcy is unnecessary. In rc J. M. Ceballos \& Co., 161 Fed. 445 (D. N. J. 1908).

55. See In re J. M. Ceballos \& Co., 161 Fed. 445, 449 (D. N. J. 1908); In re Junck \& Balthazard, 169 Fed. 481, 484 (E. D. Wis. 1909); 1 Collier on BANkruptCr (14th ed. 1940) $\$ 5.11$.

56. See note 51 supra.

57. Meek v. Centre County Banking Co., 268 U. S. 426 (1925); In re Julian, 22 F. Supp. 97 (M. D. Pa. 1938); Hunter v. Hunter \& Drew at al., 8 F. Supp. 84 (W. D. La. 1934); see note 50 supra.

58. Section $5 b$.

59. Section $5 \mathrm{~b}$ is procedurally correlated with $\$ 18 \mathrm{a}$ and $\mathrm{b}$. See Analysis, 23.

60. See Comment (1938) 87 U. of PA. L. Rev. 105, 107.

61. See Treiman, supra note 41. 
under the rule in the 1867 Act that firm property could not be administered without adjudication of all the partners. ${ }^{62}$ Like the provision of the 1898 Act allowing separate firm adjudication, it provides the supplementary machinery necessary to the solution of a problem peculiar to partnerships.

Where a partner but not the firm is in bankruptcy, a different sort of problem is presented. Here the difficulty facing the court is in getting jurisdiction, not of the firm, but of the partner's interest in the firm. That interest consists of the partner's share of the surplus after payment of firm debts. ${ }^{\text {3 }}$ It is available to the bankrupt partner's trustee for the henefit of the individual creditors, ${ }^{64}$ but it is held insufficient to give the partner's trustee any right to levy directly on the firm assets. ${ }^{60}$ Section 5 recognizes this limitation. ${ }^{60}$ but makes the partner's interest available to the trustee through machinery taken from state law. Bankruptcy of a partner dissolves the firm anl compels the winding up of its affairs. ${ }^{67}$ Section 5 therefore preserves to the nonadjudicated partners, in the absence of waiver, the right granted then under the Uniform Partnership Act, ${ }^{68}$ to wind up the firm business and account expeditiously ${ }^{69}$ to the court for the interest of the bankrupt members. ${ }^{70}$ The subsection conferring on the court with jurisdiction of one of the partners jurisdiction of the administration of the firm property ${ }^{\mathrm{il}}$ is therefore held to be limited, if the firm is not itself adjudicated, to jurisdiction by consent of the non-adjudicated partners. ${ }^{\text {2 }}$

It was formerly held that this limitation prevented the discharge of the adjudicated partner from firm debts, in view of the policy that such discharge must be based on full administration of the firm property. ${ }^{73}$ The limitation

62. See p. 909 supra.

63. UNIFORAT PARTNERSHIP ACT $\$ 2428$.

64. See Marnet Oil \& Gas Co. v. Staley, 21 S Fed 45, 48 (C. C. A. 5th, 1914); Tate v. Brinser, 226 Fed. 878, 882 (M. D. Pa. 1915); In re Laughlin, 96 Fed. 589 (N. D. Iowa 1S99) ; 1 CoLIIER ON BANRRUPTCY (14th ed. 1940) $\$ \$ 5.19,5.36$.

65. See p. 910 supra; Amsinck v. Bean, 22 Wall. 395, 401 (U. S. 1874).

66. Section 5i, 52 Stat. 845, 11 U. S. C. $\$ 23 i$ (Supp. 1938); Armstrong v. Ficher, 224 Fed. 97 (C. C. A. Sth, 1915); 1 Colrmer on Banknuptcy (14th ed. 1940) 721.

67. UnIForar PartinershiP ACT \$31(5).

68. Ibid.

69. See p. 918 infra.

70. Section 5i, 52 Stat. \$45, 11 U. S. C. \$23i (Supp. 1938); 1 Courters o: BazizRUPTCY (14th ed. 1940) $\$ 5.37$; see UNIForar Partinership ACT $\$ 37$.

71. Section 5d, 52 Stat. 845,11 U. S. C. \$23d (Supp. 1938); see note 81 injra.

72. Tate v. Brinser, 226 Fed. S7S (M. D. Pa. 1915) ; MIarnet Oil \& Gas Co. v. Staley, 218 Fed. 45 (C. C. A. 5th, 1914); see Francis v. MrNeal, 186 Fed. 481, 483-486 (C. C. A. 3d, 1911), aff'd, 228 U. S. 695, 700-710 (1913); Chemical Nat. Banls v. Meyer, 92 Fed. \$96, 898 (E. D. N. Y. 1899); 1 COLLIER ON BANKRUPTCY (14th ed. 1940) \$5.36-37.

73. In re Meyers, 96 Fed. 408 (S. D. N. Y. 1S99); Dodge v. Krufman, 46 Mise. 248, 91 N. Y. Supp. 727 (Sup. Ct. 1905). Some of the cases limited the application of the rule to the situation in which firm assets were available. In re Mreyers, 97 Fed. 757 (1899). Later cases under the 1898 Act allowed discharges regardless of the existence of firm assets. New York Inst. for Deaf and Dumb v. Crochett, 117 App. Div. 269, 27\&-230, 102 N. Y. Supp. 412, 419-420 (1st Dep't 1907). 
on the power of the individual trustee to deal with the firm assets, however, does not prevent the fulfillment of this policy, or lead to any prejudice of individual creditors, for the non-adjudicated partners will not be allowed to hinder the proceeding by delay, and the necessary consent to administration by the court is not difficult to imply. ${ }^{74}$ If, further, the necessary prerequisites of scheduling of firm debts, notice to firm creditors, and a proper request to the court for appropriate relief are complied with, the statute provicles no technical objections to a discharge from firm debts. ${ }^{75}$ Such debts are provable against the individual estate, ${ }^{\mathbf{7 6}}$ and the act allows discharge from all provable debts. ${ }^{77}$ By proving in the individual proceeding, the firm creditors are not precluded from later pursuing their remedies against the firm and the other partners. ${ }^{78}$ Thus no one is prejudiced, the requirements of the statute are met and the policy of full administration is substantially satisfied. Hence, although of course consolidation is desirable if a firm petition is pending, there can be no quarrel with the provision in the Chandler Act which specifically gives to an individual partner the right to a discharge from firm debts in a separate, as well as a joint proceeding. ${ }^{70}$

Thus, little revision of the 1898 Act was required to meet the problems presented by the situation in which some but not all the partners were adjudicated. Where, however, all the partners, but not the firm, were adjudicated, the courts found a serious procedural gap in the statute. In such a case, there is no longer any reason to reserve to any of the partners the right to wind up the firm affairs; for all of them are already before the coturt. But the courts were unwilling to construe the negative provision forbidding them to take jurisdiction without the consent of non-adjudicated partners into an affirmative grant of authority where all were adjudicated: they held that even in this situation the individual trustees had no authority over the firm prop-

74. Consent of a non-adjudicated partner can be implied from failure to object. In re Harris, 108 Fed. 517 (N. D. Ohio 1899); cf. In re Sitnek, 52 F. (2d) 861 (W. D. Pa. 1931).

75. In re Diamond, 149 Fed. 407 (C. C. A. 2d, 1906); Jarecki Mfg. Co. v. McElwaine, 107 Fed. 249 (D. Ind. 1901) ; In re Sugar Valley Gin Co., 292 Fed. 508 (N. D. Ga. 1923) ; Comment (1930) 15 ST. LouIs L. Rev. 209, 216.

76. Section 5h; In re Diamond, 149 Fed. 407 (C. C. A. 2d, 1906); Gordon v. Texas Co., 119 Me. 49, 109 Atl. 368 (1920); In re Laughlin, 96 Fed. 589 (N. D. Iowa 1899); Note L. R. A. 1918 E 470.

77. Section 17, 52 Stat. 851, 11 U. S. C. \& 35 (Supp. 1938).

78. Section 16, 30 Stat. 550, (1898), 11 U. S. C. $\$ 34$ (1934); see Jarecki Mfg. Co. v. McElwaine, 107 Fed. 249, 251-252 (D. Ind. 1901); In re Kaufman, 136 Fed. 262, 265 (E. D. N. Y. 1905).

79. Section 5j, 52 Stat. 845, 11 U. S. C. §23j (Supp. 1938). The later cases under the 1898 Act had reached this result. In re Laughlin, 96 Fed. 589 (N. D. Iowa 1899); Gordon v. Texas Co., 119 Me. 49, 109 Atl. 368 (1920); New York Inst. for Deaf and Dumb v. Crockett, 117 App. Div. 269, 102 N. Y. Supp. 412 (1st Dep't 1907) ; 1 Collier ON BANKRUPTCY (14th ed. 1940) $\$ 5.15$. 
erty without a separate firm adjudication. ${ }^{80}$ There seems no reasun why the courts could not have allowed the administration of the firm property without firm adjudication under the subsection giving the court with jurisdiction of one of the partners jurisdiction of the administration of the firm property $; 81$ but the Chandler Act has now removed the difficulty and provided the standard basis for administration by ruling that where all the partners are adjudicated, the firm shall also be adjudicated. ${ }^{82}$ This allows the rules for venue and ancillary jurisdiction worked out by the courts under subsection $5 \mathrm{~d}$ and General Order VI to be applied without procedural inconvenienee. ${ }^{83}$

The need for an automatic firm adjudication to provide a basis for the administration of the firm property, where all the partners have heen adjulicated, arises from the treatment of the firm as a separate "person" fur purposes of adjudication. If the firm were to be treated as a "person," the courts felt, its property should be administered only when the prerequisites to alministration of the estates of individuals had been met. ${ }^{8 t}$ This view of the firm as a separate "entity" has had more serious consequences in blurring the distinction between the rights and liabilities of the partners as individuals and as members of the firm, and has made it difficult for the court to deal adequately in a firm proceeding with the assets of unadjudicated partners: ${ }^{85}$ The difficulty is partly the result of faulty analysis. A firm cannot lie effectively dealt with for all purposes as an "entity." 80 It can be separately adjudicated a bankrupt; but that rule should be limited to its proper function of enabling the court to take jurisdiction of the fund of assets used in the partnership business when some of the partners cannot be individually adjudi-

80. In re Mercur, 116 Fed. 655 (E. D. Pa. 1902), aff'd, 122 Fed. 384 (C. C. A. 3d, 1903 ) ; Ludowici Roofing Tile Co. v. Pennsylvania Inst. for Blind, 116 Fed. 661 (E. D. Pa. 1902) ; see Amsinck v. Bean, 22 Wall. 395, 401 (U. S. 1874); 1 CoLLren 0: Ba:iriRUPTCY (14th ed. 1940) 741 , n. 1 .

81. Section 5d, 52 Stat. $\$ 45,11$ U. S. C. $\$ 23 d$ (Supp. 1938). This provision is virtually the same as that included in the $1 S 98$ Act. $\$ 5$ c, 30 STAT. 547 (1S98), 11 U.S.C. $\$ 23 \mathrm{c}(1934)$. $\$ 5 \mathrm{~d}$ reads: "the court of bankruptcy which has jurisdiction of one of the general partners may have jurisdiction of all the general partners and of the administration of the partnership and individual property."

82. Section 5i, 52 Stat. \$45, 11 U. S. C. \$23i (Supp. 1938); Analysis, 25, n. 10; 1 Coltier on BANKRUPTCY (14th ed. 1940) $\$ 5.38$.

83. In re Flaherty, 265 Fed. 741 (N. D. Iowa 1920), modificd on ather grounds $s u b$ nom. Carter v. Whisler, 275 Fed. 743 (C. C. A. Sth, 1921) (discussing venue and ancillary jurisdiction); 1 CoLIIER on BANKRUpTCY (14th ed. 1940) $\$ 5.16$. General Order VI and $\$ 32,52$ STAT. 857,11 U. S. C. $\$ 55$ (Supp. 1938) regulate transfer of jurisdiction from one district court to another.

S4. See In re Mercur, 116 Fed. 655, 658 (E. D. Pa. 1902), aff'd, 122 Fed. 384,339 (C. C. A. 3d, 1903).

85. In re Bertenshaw, 157 Fed. 363 (C. C. A. Sth, 1907); In re Everybody's Grocery and Meat Market, 173 Fed. 492 (D. Okla. 190S) ; cf. Francis v. MeNeal, 228 U. S. 695 (1913) ; Comments (1928) 41 Harv. L. Rev. 1044, (1929) 29 CoL L. Rev. 1134 (1911) 10 MiCH. L. Rev. 215, (1908) S CoL L. Rev. 391.

86. Analysis, 21 ; Comments (1929) 29 CoL. L. Rev. 1134, (1929) 23 ILI. L. Rev. 483. 
cated. ${ }^{87}$ Further, the firm and partners must be separately treated for purposes of the rule of distribution, ${ }^{88}$ incorporated into the bankruptcy act from state law, ${ }^{89}$ which provides that individual creditors shall have first claim on individual assets, firm creditors first claim on firm assets. ${ }^{00}$ There has been a good deal of criticism of this rule on the ground that, since the claim of firm creditors to individual assets is stronger than that of individual creditors on firm assets, it is unfair to put the two classes on a par. ${ }^{01}$ Such criticism is not without justification. The existing rule, however, is of very long stancling, and is generally admitted to be a fairly workable, if somewhat crtude compromise between the rights of firm and individual creditors ;2 it is readily understandable that it should be reenacted in the Chandler Act, unchanged except for a provision for distribution of the surplus of firm assets in the order provided by the applicable state law..$^{93}$ It has no real exceptions ${ }^{04}$ and a disposition of the firm property which defeats the priorities which it establishes may be set aside as a fraudulent or preferential transfer. ${ }^{05}$

The firm and partners are also treated separately for purposes of the trustee's accounts. ${ }^{96}$ Because of the priority of the firm and individual credi-

87. See p. 909 supra.

88. Section $5 g, 52$ StAT. 845,11 U. S. C. \$23g (Supp. 1938).

89. Uniford Partners hip Act $\S 40 ; 1$ Collier on Bankruptcy (14th ed. 1940) 724.

90. See Francis v. McNeal, 228 U. S. 695, 700 (1913) ; Rodgers v. Meranda, 7 Ohio St. 179, 181 (1857) ; CRANE, Partnership (1938) 403 et seq.; Shroder, Distribution of Assets of Bankrupt Partnerships and Partners (1905) 18 HARv. L. Rev. 495.

91. Shroder, Distribution of Assets of Bankrupt Partnerships and Partners (1905) 18 HaRv. L. Rrv. 495, 504. The rule of distribution appears in the bankruptcy law of no other country except England. Brannan, The Separate Estates of Non-Banlirupt Partners in the Bankruptcy of a Partnership under the Bankruptcy Act of $189 S$ (1907) 20 HaRv. L. Rev. 589, 592.

92. See Rodgers v. Meranda, 7 Ohio St. 179, 182 (1857).

93. Section 5g, 52 Stat. 845, 11 U. S. C. $\$ 238$ (Supp. 1938). See Unıfora PaktNership ACT $\$ 40$, and UntForar Limited Partnership ACT $\$ 23$.

94. Section $5 \mathrm{~h}$ ( $\$ 5 \mathrm{~g}$ of the $1898 \mathrm{Act}$ ), which provides for marshaling the assets of partnership and individual estates to ". . . secure the equitable distribution of the property of the several estates" has been uniformly held to strengthen and execute, not to limit, $\S 5 \mathrm{~g}$ ( $\S 5 \mathrm{f}$ of the $1898 \mathrm{Act}$ ). See Comment (1940) 49 YALE L. J. 686, 695, 696, n. 48. An apparent exception to the rule of $\$ 5 \mathrm{~g}$ appears in cases allowing a firm creditor who has received from a partner separate security for his debt, to share pari passu with the partners' individual creditors. Mitchell v. Hampel, 276 U. S. 299 (1928); Buckingham v. First Nat. Bank, 131 Fed. 192 (C. C. A. 6th, 1904) ; Fourth Nat. Bank v. Mead, 216 Mass. 521, 104 N. E. 377 (1914). A real exception existed in the early rule permitting firm creditors to share pari passu in the partners' individual estates if there were no firm assets. Conrader v. Cohen, 121 Fed. 801 (C. C. A. 3d, 1903) ; 1 Collier on BankRUPTCY (14th ed. 1940) $\$ 5.27$. The irrationality of the exception was soon exposed. In rc Wilcox, 94 Fed. 84 (D. Mass. 1899); In re Janes, 133 Fed. 912 (C. C. A. 2d, 1904); Farmers' \& Mechanics' National Bank of Philadelphia v. Ridge Avenue Bank, 240 U. S. 498 (1917).

95. Comment (1940) 49 Yale L. J. 686.

96. 1 Collier on BANKRUPTCY (14th ed. 1940) §5.20. 
tors to the funds on which they have primarily relied, it is of course necessary that the firm trustee keep separate accounts of the different estates in his charge, and the Act so provides. ${ }^{97}$ This function is generally allotted to the firm trustee even in a joint proceeding. But because of a recognition of the fact that there may be occasions when, because of conflict of interest or procedural inconvenience, the best interests of the individual partners may require separate trustees to administer the individual estates, the Act has specifically authorized the appointment of a separate trustee for cause shown. ${ }^{83}$

The separate treatment of the partners for purposes of accounting and distribution, however, is grounded, not on any mysterious separate personality of the firm, but on the fact that the partners have, as individuals, rights and liabilities distinct from those incident to their relation to the firm. The fact that they must first pay their individual debts does not affect the fact that they are liable for all the firm debts. ${ }^{90}$ Because of that liability, the surplus of their assets over their individual debts is a firm asset ${ }^{100}$ which must be considered in determining the question of firm solvency.101 Because of that liability too, the firm trustee has a direct right against the individual assets available to him, and those assets must be drawn into the firm proceeding ${ }^{102}$ or at least accounted for. Individual adjudication should be relevant only to the handling of the assets allocated to the payment of individual debts; a firm adjudication should give the firm trustee power to dispose of all relevant assets, and the court power to discharge all liability for firm debts.

Unfortunately the Bankruptcy Act, in attempting to engraft the partnership section on the structure already worked out for individuals, does not adequately distinguish between the rights and liabilities of the partners incident to the firm proceeding and those incident to an individual proceeding; and the logomachical dispute over the entity theory has made it difficult for the courts to keep this important distinction in mind. As a result, cases under the 1898 Act at first denied the court any power at all over the estates of partners with respect to whom the usual basis of jurisdiction, adjudication, was lacking. ${ }^{103}$ The statute, when it permitted the adjudication of the firm without that of all the partners, did not clearly provide a new basis for the necessary action with regard to unadjudicated partners. Under Section $5 c$ of that Act, the court with jurisdiction of one of the partners was given jurisdiction of the others and of the administration of the firm and separate

97. Section 5e, 52 Stat. $\$ 45,11$ U. S. C. \$23e (Supp. 193S).

98. Section 5c; Analysis, 23.

99. See Francis v. $M I$ cNeal, 228 U. S. 695,699 (1913); Diclas v. Barnes, 140 Fed. 849,851 (C. C. A. 6th, 1905).

100. See note 18 sipra.

101. See Francis v. MicNeal, 228 U. S. 695, 700-703 (1913); note 19 stspra.

102. See note 20 supra.

103. In re Bertenshaw, 157 Fed. 363 (C. C. A. Sth, 1907); In re Solomon \& Carred, 163 Fed. 140 (E. D. N. Y. 190S) ; Comments (190S) \& CoL. L. REv. 391, (1912) 10 MIrCH. L. REv. 215. 
estates. ${ }^{104}$ The term "jurisdiction," as first used in that section, seems clearly referable to questions of venue and the proper forum, and the main application of the section has been to questions of this sort. ${ }^{105}$ The problem is therefore presented as to whether, if "jurisdiction of one of the partners" refers to general jurisdiction of the person rather than to the presence of the statutory prerequisites to bankruptcy action, the grant of juriscliction of administration contained in the second clause of the section can fairly be interpreted as an affirmative grant of power over all the estates. The famous case of Francis $v$. McNeal ${ }^{\mathbf{1 0 6}}$ held that it could and that the estate of an unadjudicated insolvent partner could be drawn into the firm proceeding. In view, however, of the fact that not all acts of bankruptcy involve an allegation of insolvency, ${ }^{107}$ doubt remained as to whether this power existed in the case of a solvent partner, ${ }^{108}$ and cases reaffirming the doctrine of separateness of firm and partners rather indicated that the rationale of the $M c N e a l$ case might be limited to its facts. ${ }^{100}$ It now seems, however, that at least in the reenactment of the subsection in the Chandler Act, a broad view of the $\mathrm{McNeal}$ case was adopted and an affirmative grant of authority was intended. ${ }^{110}$ In the subsection authorizing the appointment of a separate trustee, ${ }^{111}$ adjudication of the individual partner is required, for procedural reasons, as a prerequisite; but adjudication of the partners is omitted as a requirement of administration of the separate estates by the firm trustee. The distinction seems to have been purposive.

It seems, then, that under the Chandler Act the firm trustee has the power to administer the estates of unadjudicated partners regardless of their individual solvency. ${ }^{112}$ But even under the new Act the power is not coextensive with the needs of adequate administration. Since the surplus of individual assets over individual debts is a firm asset, the firm trustee should have all the normal powers of a bankruptcy trustee to prevent the diminution of that asset by the partner. But the reasoning of Liberty National Bank v. Bear ${ }^{113}$ indicates that liens on the individual property of the partners are not affected

104. Section 5c, 30 StaT. 547 (1898), 11 U. S. C. \$23c (1934).

105. In re Mitchell, 211 Fed. 778 (S. D. N. Y. 1914); see Meek v. Centrc County

Banking Co., 268 U. S. 426, 431 (1925); note 83 supra.

106. 228 U. S. 695 (1913).

107. See note 46 supro.

108. See Comment (1929) 29 CoL. L. Rev. 1134.

109. Liberty Nat. Bank v. Bear, 276 U. S. 215 (1928) ; Comment (1929) 29 Cot. L. REv. 1134.

110. See note 81 supra.

111. See note 98 sitpra.

112. Armstrong v. Fisher, 224 Fed. 97, 99 (C. C. A. 6th, 1905); Dickas v. Barncs, 140 Fed. 849, 851 (C. C. A. 6th, 1905) ; In re Sugar Valley Gin Co., 292 Fed. 508, 509 (N. D. Ga. 1923) ; Comment (1929) 29 Col. L. Rev. 1134, 1136; 1 Collier on BANKRUPTCY (14th ed. 1940) \$5.19.

113. 276 U. S. 215 (1928). 
by a firm adjudication. ${ }^{114}$ The case has been considered as reaffirming the entity theory of partnership bankruptcy. ${ }^{115}$ A sounder view is that although the policy of full administration of all firm assets requires power of the firm trustee to set aside liens on the individual property of the partners, Section 5 fails to provide a substitute for the usual basis for this power - individual adjudication. ${ }^{116}$

Section 5 has left unsolved a number of other problems incident to the administration of the estates of unadjudicated partners. Is such administration optional to the firm trustee? Or can the firm creditors compel it:117 The directions of the statute with regard to the duties of trustees in their handling of the estates of bankrupts ${ }^{118}$ are of course not directly applicable to non-bankrupt partners' estates. But the firm trustee should be compelled to administer all assets of the firm, including the available assets of the partners; unless he does so, he does not take all action necessary to effective administration of the firm estate, nor provide the basis for discharge of the partners from firm debts. ${ }^{119}$

Again, the Act leaves doubt as to what the firm trustee should do with the assets determined to be referable to the individual debts of the non-adjudicated partners. Should he return them to the partner or pay them direetly to the creditors? The correct answer seems to be that he should return such assets to the partners. ${ }^{120}$ It is desirable that unified administration be achieved by a joint proceeding which can treat both individual and firm debts. But the option of using such a proceeding should be left to the partners or their creditors. ${ }^{121}$ The policy of drawing into the firm proceeding the estates of the partners in all cases seems justified so far as those estates are relevant to the firm proceeding; in his capacity as partner, liable for the firm debts, an individual may fairly be said to have abandoned exemption

114. Ibid.; Comment (192S) 41 Hanv. L. REv. 1044, 1046.

115. Comment (1929) 14 St. Lours L. Rev. 179, 180; 1 Coluter on Banisnutrer (14th ed. 1940) $\$ 5.03$.

116. Section $67 \mathrm{a}(1), 52$ STat. 875,11 U. S. C. $\$ 107 a$ (1) (Supp. 1938).

117. Some cases consider the administration of the non-adjudicated partners' estates as compulsory. In re Sugar Valley Gin Co., 292 Fed. 50 S (N. D. Ga. 1923); Matter of Georgalas Bros., 245 Fed. 129 (N. D. Ohio 1917). 1 Collies on Businsurser (14th ed. 1940) $\$ 5.19$, n. 1. The issue, however, is controversial. Compare Comment (1929) 41 Harv. L. Rev. 1044, with Comment (1929) 29 CoL. L. Rer. 1134.

11S. Section 47, 52 Star. $\$ 60,11$ U. S. C. $\$ 75$ (Supp. 1938).

119. Without full administration, discharge of the partners from firm debts is unjustified as a matter of policy. See p. 924 infro. Therefore, if administration of the separate estates of unadjudicated partners is discretionary to the firm trustee, no individual discharge from firm debts could fairly be made without consideration of what the trustee had done in the particular case. See Comment (1929) 29 Cor. L. Rew. 1134. Of course, under the Chandler Act, discharge of individual partners from firm debts is never possible without individual adjudication. $\$ 5 \mathrm{j}$.

120. Comment (1928) 41 Harv. L. Rev. 1044, 1047.

121. Ibid.; Comment (1929) 29 CoL. L. REv. 1134, 1137. 
under the Act from bankruptcy. ${ }^{122}$ But with regard to the individual obligations of the partners, there is no reason why the usual bases of bankruptcy jurisdiction should not be met.

Perhaps the most conspicuous example of the failure of the 1898 Act to solve the problems peculiar to partnerships was its lack of provision for the discharge of the partners from the firm debts. The provision of the 1867 Act for discharge of the partners was omitted from the Act of $1898,{ }^{123}$ and most courts held under the latter statute that, upon its general policy, discharge could be predicated only on prior adjudication. ${ }^{124}$ As a matter of policy this was again a result of the failure to distinguish between the partners as individuals and as members of the firm. If the partners' estates are considered in measuring firm solvency, and the partners themselves submitted to most of the burdens of bankruptcy through the administration of their estates in the firm proceeding, ${ }^{125}$ it is indeed an "incongruity" ${ }^{120}$ to deny a discharge of firm debts after all firm creditors' rights have been satisfied. A discharge of the firm "entity," leaving the partners fully liable at law, is a plain absurdity ; and under the doctrine of administration of all separate estates, there is no reason why the unadjudicated partners should not be granted a discharge.

Of course, such a discharge should not be granted zoithout full administration of the individual estates. ${ }^{127}$ Any provision for individual discharge from firm debts must therefore be predicated on a solution of the administrative uncertainties discussed: there should be authority for the firm trustee to deal adequately with the individual estates, and liens on them; he should be compelled to administer all the individual estates, and instructed what to do with the assets not available to firm creditors; and the doubts as to the extent of application of the $M c N e a l$ doctrine should be laid at rest. If this were done, there would be no reason of policy why the "incongruity" should not be removed; and such holdings as that of a recent case ${ }^{128}$ under the Chandler Act that the court has a limited jurisdiction over the assets of unadjudicated partners, but none over rights of action against them, would be avoided.

Some courts under the 1898 Act did, on the basis of the arguments in the McNeal case, disregard the "technical" objection of lack of individual

122. See Dickas v. Barnes, 140 Fed. 849,851 (C. C. A. 6 th, 1905).

123. Analysis, 26; see p. 909 stipra.

124. Horner v. Hamner, 249 Fed. 134 (C. C. A. 4th, 1918); In re Pincus, 147 Fed. 621 (S. D. N. Y. 1906) ; Bloyd v. Williams-Echols Dry Goods Co., 167 Ark. 644, 268 S. W. 618 (1925) ; Rowland v. Lovett, 45 Ga. App. 122, 163 S. E. 511 (1932); Wm. R. Moore Dry Goods Co. v. Ford, 146 Ark. 227, 225 S. W. 320 (1920); 1 COLLIER on BANKRUPTCY (14th ed. 1940) $\$ 5.15$; see note 125 infra.

125. See Comments (1929) 29 Cor. L. Rev. 1134, (1922) 22 CoL. L. Rev. 348.

126. See Francis v. McNeal, 228 U. S. 695, 701 (1913); Comment (1925) 35 YALE L. J. $362,365$.

127. See Comment (1928) 41 HaRv. L. Rev. 1044; note 125 supra.

128. First Nat. Bank of Herkimer v. Poland Union, C. C. A. 2d, Jan. 8, 1940. 
adjudication, and grant discharge from firm debts to unadjudicated partners. ${ }^{129}$ But the "technical" objection has a good deal of weight, and it was the job of the revised statute to supply a statutory basis for the action which policy so clearly indicated. Instead, the Chandler Act specifically forebade discharge of the partners without adjudication. ${ }^{130}$ The provision was inserted on the theory that it was settled law. ${ }^{131}$ This approach seems based on a fundamental misconception of the function of statutory reform. The "settled" law was made up of cases based on mistaken and inadequate premises. ${ }^{132}$ Their analysis was warped by their obsession with the dnctrine of firm separateness; and they were handicapped by the absence of any permission in the act justifying the grant of a discharge. The Chandler Act has replaced inadequacy with forthright prohibition, and codified cases themselves based on lack of authority.

This codification of the harsh discharge provision is not justified by the availability of discharge from firm debts on an individual adjudication. The drafters of the Act themselves ignored a similar argument when they provided for automatic adjudication of the firm on adjudication of all partners, and for a quasi-voluntary petition by less than all the partners. In both these cases, relief was available by more roundabout, cumbersome proceedings. 133 Further, the relief provided by a discharge from firm debts on an individual petition is not equivalent to that gained by discharge of non-adjudicated partners in a firm proceeding. It requires the partner, whether or not he has committed an act of bankruptcy, and even if he is exempt under the statute, to submit all his property to the court, if he is to be discharged from his firm debts. There is no justification for so strict a requirement. If the interests of firm creditors are protected, there is no reason why the court should force the partner, on pain of a denial of discharge from firm debts, to submit his individual assets to the court unless he so wishes, or has made

129. Armstrong v. Norris, 247 Fed. 253 (C. C. A. Sth, 1917); Abbott v. Anderson, 265 Ill. 285,106 N. E. 782 (1914) ; Young v. Stevenson, 73 Ark. 480, 4 S. W. 623 (1905), averruled sub nom. Bloyd v. Williams-Echols Dry Goods Co, 167 Arls. 644, 263 S. W. 618 (1925).

130. Section 5j, 52 Stat. $\$ 45,11$ U. S. C. \$23j (Supp. 1938).

131. Analysis, 26.

132. Horner v. Hamner, supra note 124, was the case on which the drafters of the Chandler Act apparently chiefly relied as "settled" authority for the denial of a discharge. Analysis, 26-27. The Homer case, however, placed much reliance on In re Bertenshaw, 157 Fed. 363 (C. C. A. Sth, 1907), a strict entity theory case which at the time of the drafting of the Chandler Act had been peacefully buricd for a quarter of a century. See note 48 sipra.

133. Jurisdiction to administer the firm property could of course be attained by the filing of a new petition against the firm. And a partner could get a discharge from firm debts on a separate voluntary petition. See p. 918 stpra; Comment (193\$) \$7 U. of PA. L. Rev. 105, 107. 
himself subject to an individual involuntary petition under the provisions of the Act pertinent to individuals. ${ }^{134}$

There is thus under the present statute little point to the partner's resisting adjudication even where he could successfully do so. The cases which rule that any act of bankruptcy for which the firm can be adjudicated allows the adjudication of all the partners ${ }^{135}$ achieve, curiously, the result most favorable to the partners, since without such adjudication they are denied a discharge from firm debts. Yet these cases fail to draw any distinction between the rights and liabilities of the partners as individuals and as members of the firm, and, under a statute which provided an adequate basis for discharge of the partners from firm debts, could be justly criticized.

It is thus apparent that the method of reform used in the Chandler Act, though it has eliminated some procedural gaps and uncertainties, has failed to solve the most important problems of partnership bankruptcy. By relying heavily on the cases under the old Act, it has preserved the taint of dialectical controversy over the theoretical separateness of the firm, and has continued the statutory inadequacies which were responsible for many of the faults in the decisions. By continuing to rely on the sections of the Act worked out for individuals, it has failed to give the firm trustee sufficient authority to deal adequately with the assets of unadjudicated partners, or the court the power to discharge such partners after the proceeding. There seems no reason why there should not be provided for the partners and their assets, so far as they are relevant to the firm proceeding, a machinery separate from that based on their adjudication as individuals. Such machinery, so fitted to the rules of partnership law as to make possible the fulfillment of the aims of bankruptcy - efficient administration, satisfaction of creditors and a new start for the debtor - the Chandler Act failed to provide. It is to be hoped that the courts will succeed in avoiding the dialectical controversy which has clouded so many issues under the old statute, and will devote their energies to close analysis of the fundamental rules of partnership law in order to achieve the aims of bankruptcy so far as this is not affirmatively prevented by the Act. It is unfortunate that the Chandler Act has made this task so difficult, by attempting to patch a fabric which should have been completely rewoven.

134. The inconsistencies of the present Act are also illustrated by the curious tactical dilemma which faces the firm creditor. He might well wish to avoid separate adjudication of the partners, so as to take the benefits of administration of the assets of partners in the firm proceeding [see $\$ 5 \mathrm{~d}]$, while leaving the partner fully liable for firm debts under $\$ 5$ j. But under the doctrine of the Bear case, the creditor may be forced to get separate adjudications of the partners if he is to prevent liens on their individual estates from becoming indissoluble.

135. See note 45 sipra. 